\title{
Brazil, Canada And China: A Cross-Compare Study Of Its Educational Indicators
}

\section{Brasil, Canadá E China: Um Estudo Comparativo De Seus Indicadores Educacionais}

\author{
Danilo de Melo Costa ${ }^{1}$ \\ ${ }^{1}$ Centro Universitário Una, UNA, Brasil. \\ Correspondência: Danilo de Melo Costa. Rua dos Guajajaras, 175, Sala do Mestrado, Centro, CEP 30.180-100, \\ Belo Horizonte, MG, Brasil. Telefone: +55 (31) 3508-9141. E-mail: danilomct@ gmail.com.
}

Recebido: 31 de janeiro de 2018 Aceito: 28 de setembro de 2018 Publicado: 28 de dezembro de 2018

DOI: http://dx.doi.org/10.21714/1679-18272018v16n1.p1-15

\begin{abstract}
In a globalized world, nations need to follow the development and performance of their peers. Therefore, the study aims to analyze the educatonal indicators in Brazil, Canada and China with the goal to identify the behavior of these indicators as a way to signal benchmarking and learning opportunities. For that, a descriptive quantitative research was performed, through the collection of documentary and bibliographic data from databases worldwide. In order to understand the performance of the educational indicators from the countries, a comparative analysis by regression models via log-linear Quasi-Likelihood method was carried out. The goal was to understand the performance of each indicators in their countries in order to understand their behavior in the 2003-2012 period. The conclusions showed that Canada is a country that has already achieved a high level of development, including its higher education, and that can be considered a reference for other nations seeking to achieve similar progress as Brazil and China itself. In addition, China, a member of BRICS, which is a pair of Brazil, has been able to achieve satisfactory results in the indicators that guide higher education, which highlighted the advantages of conducting a benchmarking of their actions and policies.
\end{abstract}

Palavras-chave: Brazil; Canada; China; Cross-compare Study; Higher Education.

\section{Resumo}

Em um mundo globalizado, as nações precisam seguir o desenvolvimento e o desempenho de seus pares. Portanto, o presente estudo pretende analisar os indicadores educacionais do Brasil, Canadá e China, com o objetivo de identificar o comportamento desses indicadores como forma de benchmarking e oportunidades de aprendizagem. Para isso, foi realizada uma pesquisa quantitativa descritiva, através da coleta de dados documentais e bibliográficos de bases de dados em todo o mundo. Para entender o desempenho dos indicadores educacionais dos países, foi realizada uma análise comparativa por um modelo de regressão log-linear via método de QuaseVerossimilhança. $\mathrm{O}$ objetivo foi verificar o desempenho de cada indicador em seus países para compreender seu comportamento no período 2003-2012. As conclusões mostraram que o Canadá é um país que já alcançou um alto nível de desenvolvimento em sua educação superior, e que pode ser considerado uma referência para outras nações que procuram alcançar um progresso similar, como o Brasil e a própria China. Além disso, a China, membro do BRICS, que é um par do Brasil, conseguiu resultados satisfatórios nos indicadores que orientam a educação superior, o que sinaliza as potenciais vantagens de se realizar uma avaliação comparativa de suas ações e políticas.

Keywords: Brasil; Canadá; China; Estudo comparativo; Educação superior.

Esta obra está licenciada sob uma Licença Creative Commons Attribution 3.0.

\section{Introduction}

Higher education has always played a major role in the success of nations, however, in recent decades, the importance of this education level has beenboosted. New ways of working were introduced in organizations and information has become the most important strategic asset for companies, because it is now available faster and in more locations around the world, breaking unimaginable ties until then.

To carry out the management of strategic asset that, higher education is now considered one of the main factors 
responsible for giving subsidy to the nations participating in the phenomenon of globalization and seeking a solid and lasting growth.

The importance of the variable "education" has been considered by several countries seeking through this major policy for the country's progress. According to studies by the Inter-American Development Bank (IDB), "Entrepreneurship in emerging economies: Creation and Development of New Firms in Latin America and East Asia," the training of potential entrepreneurs is a long process that begins during the first cycle of education and extends to the university and the first years of work (BID, 2002), demonstrating the need to create public policies that finance higher education in order to meet the aspirations of the country.

This practice development through investment in higher education already confirmed in Canada, which for many years has invested heavily in education, achieving significant rates of young people between 18 and 24 years enrolled in higher education (HADDAD; GRACIANO, 2004).

In Asia, you are able to watch a real phenomenon, as the continent grows as much as it invests in education. In recent years, the Asian discovered this formula of success and began to invest heavily both in basic education and in higher education. Countries like China is now conducting research within itsr own universities and then commercialize the results, as well as increasing investment in higher education (MAHMOOD; SINGH, 2003).

In South America, with emphasis on Brazil, the funding is mainly through public policies, such as: Support Program Plan of Restructuring and Expansion of Federal Universities - Reuni (now closed), University for All Program - Prouni; Higher Education Student's Fund Financing - Fies; Federal Institutes of Education, Science and Technology- IFETs; and Open University of Brazil - Uab. While investments are happening and should be highlighted, they are still of short need in the country, especially if compared to other countries such as Canada and China.

From then on, it is observed a gap to be explored regarding the proposition of structural changes and new public policies, taking as reference the results of other nations. For this reason, this study uses as a reference the educational indicators in Brazil, Canada and China, based on the assertion of Lang and Zha (2004, p. 341) who argue that "Comparisons between pairs can provide a basis for a rational assessment of the differences and similarities, and identification of strengths, weaknesses, and potential opportunities or niches."

In addition to the continental dimension, characteristic of the three countries, the reason for this choice is linked to several factors.

Canada, besides being a developed and strong economy, has one of the most advanced educational systems in the world, and based on good European and American practice (CATTANI, 2006). In addition, Brazil and Canada have a strong agreement for the development of joint research, through the International Partnership of Science and Technology from Canada (ISTPCanada) (ISTPCanada, 2017). Moreover, Cattani (2006, p. 52) shows that Canada and Brazil have many similarities:

[...] the two are New World countries, with almost equivalent continental dimensions; both have immeasurable availability of natural resources; the beginning of theireffective colonization, unlike the former Spanish colonies, occurred more than a century after the arrival of Europeans; the occupation and the subsequent exploitation of the territory took place under very close modes (coureurs des bois and pioneers); most of its immigrants consisted of disqualified people for productive employment (convicts, orphans, military). In the late eighteenth century the estimated number of inhabitants was, surprisingly, almost the same. Moreover, in Brazil and in French Canada, it was remarkable the presence of religious orders of the Catholic Church and the existence of strong dependence on ties with the European metropolises, such links that long prevented the emergence of industrial capitalism.

China had one of the largest economic growths in history and also improved the access and retention indicators in education, which can be exemplified by the growth of $337.5 \%$ in the gross enrollment rate in tertiary education between the years 1999 and 2006 (UNESCO 2008). China represents one of Brazil's peers and also is a developing country participant in BRICS ${ }^{1}$. For this reason, both countries founded an academic cooperation through the "Seminar on Strengthening Higher Education Internationalization: Opportunities for Brazil and China," organized by the China Scholarship Council (CSC) and the Education Personnel Improvement Coordination Superior (Coordenação de Aperfeiçoamento de Pessoal de Nível Superior, CAPES) (CAPES, 2012).

From this information, this research is relevant because it understands that the behavior of educational indicators in recent years will show the importance of analyzing the countries studied more deeply and also the advantages of Brazil to structure possible partnerships with Canada and China in order to comprehend phenomena and policies that have led to such results and could be adapted to the country. 


\section{Theoretical Framework}

The seek for progress, democratization, access to the common good and reducing inequality is a problem that has been fought for decades in Brazil, challenging public policies and economic theories developed for this purpose. Pigatto et al. (2010, p. 821), asks: "[...] why after so many years of investment it still cannot achieve a reasonable degree of development?".

In order to strengthen relations between public administration and the performance of higher education, this section explores planning, finance and public budget followed by the world higher education challenges.

\subsection{Planning, Finance And Public Budget}

According to Polo (2009), planning and budgeting are mixed in public administration. The author explains that, with respect to the public sector, the budget has been in practice, one of the only steps used in a planning system, but being perceived as a legal instrument, in which the executive branch gets legislative authorization to perform public spending. This lack of an effective planning process of the public sector makes the focus on the financial dimension grows, by means of public finances and the public budget process.

Under these circumstances, budgeting, whosegoals should only become viable and compatible set out in the decision-making process (Multi-Year Plan) with the available resources, shall exercise simultaneously the two roles: budgeting and planning (POLO, 2009, p 18.).

Note that since its inception, public finances concluded that the most objective is to enable the Federal Government's responsibilities. This analysis is guided in understanding the collection and use of resources for a predetermined order. The setting is usually associated with people's needs, to meet the public interest of the majority, therefore, the Federal Government should take care to not only get the resources, but also manage them and apply them through the known requirements. For D'Auria (1962, p. 63) public finances "[...] in its vast and limitless activities, face and resolve the problems of an economic nature that trigger the government function, from which it follows that the function financial falls under the political and economic order of the Federal Government".

Silva (2004) believes that, so that public resources are allocated efficiently, incentive mechanisms should be defined, aimed at prioritizing the effectiveness of public spending and especially the improvement of social indicators, as investments in health and education represent a positive impact with regard to the country in productivity and hence workers' income. In a study of consolidation of various indicators, it was shown to the extent the number of members of a Brazilian family with the third degree increases, as the investment by the family in higher education is also increased, demonstrating that as a first step the government, the population itself can feed back the investment in higher education (COSTA; COSTA, MELO, 2011).

However, for that intent, it is intended the required amount to the above sectors, the government needs resources that will be the basis to develop public policies and social actions that should designate their resources for the entire population. It is through obtaining public revenues that this whole process is designed (FUNG, 2004). Therefore, the proper management and use of financial resources represent improvements in social, administrative and economic aspects of public management, which will grant to fund the public funds activities from companies and people who will go to the government, performing a financial cycle from a society-state partnership (MATIASPEREIRA, 2006).

The society-state relationship then proceeds to guide the precepts of the area of public finances. Summarily, public finances should be concerned first with the activity of raising the funds through the tax of the government policies, and subsequently with the application of funds raised through a budgetary policy in order to meet the needs of the population (MATIAS-PEREIRA, 2006).

In this scenario, the government has a crucial role as it will be responsible for managing and allocating the necessary resources in public services that meet the interests and aspirations of society, either at the federal, state or local level (MATIAS-PEREIRA, 2006).

To meet these aspirations, which are growing, public entities need to manage public resources, turned directly to the implementation of activities that are of public interest, both as a state organization and as a community population (BOBBIO, 1986). It is then up to the government to conduct the public initiatives, as a tool Branches and agencies that compose it to meet the company's needs with services, activities and quality of public policies (MEIRELLES, 2012). To Matias-Pereira (2006), the search for an efficient public management then starts to represent a major challenge to the Federal Government, at all levels, it will involve an understanding of the demands of society and, from that, to trace the appropriate action, which involves planning, direction, control, among many other activities. In order to achieve effectiveness in these actions, a proper management of financial 
resources is needed, something that can be achieved by a well-designed budget.

The budget may be visible as a managerial tool that allows managers to evaluate the financial performance of an organization, its positive and negative impacts, the changes that occur in a given period of time, in order to understand in a macro and a micro environments, the application of financial resources, thus, the budget, both in public and in private initiative, concerns the composition of the interests of their organizations, showing different needs for each environment (GIACOMONI, 2012).

Since there is no change strategies in organizations, in any administrative dependence, there is also a budget amendment, which ultimately reflects these changes.

The budget has been practiced for many years, as noted by Deodado (1965), Lee and Johnson (1977) and Giacomoni (2012). The authors report that from feudalism to modern society, this instrument is a key to achieving greater transparency, control, planning and decision aid when applying the financial resources in organizations.

As regards the public area, budgetary practice has become a tool even for monitoring the population against their rulers, considering that they should try to allocate the necessary resources to address the demands of society. Based on the observed results (for example, education, safety, health, among other areas) the officials may have a hard recovery of the population (PAYSANT, 1999).

From then, it is evident the important role played by the Federal Government in the context of public finances and the public budget. Crozier (1996) believes that the Federal Government should seek more effective action and have to set targets to avoid the generation of vague and inconsistent results.

\subsection{World Higher Education Challenges}

At the end of the first decade and the beginning of the second decade of this century, many nations, especially those developed, have faced one of their greatest financial crises. Continents hitherto economically sound, like North America and Europe are the main affected, especially the United States, which shall have its hegemony threatened by China (SAWAYA, 2009). That situation makes these continents start to rethink a number of cyclical changes and even structural seeking resume good growth rates.

Amid the unwanted situations, some instruments are now considered essential to improve economic indicators, including higher education, which is responsible for several factors that have a direct impact on the results of the economy, such as:

a) generation of labor, skilled labor, which causes direct impact on productivity and consequently in job creation;

b) innovation discoveries, which when well-marketed can also help in the economic progress of countries and generating jobs;

c) creation of new business and maintain existing business, by training entrepreneurs.

Factors such as these make the nations start to give even more attention to higher education and funding should be allocated for such, as the United States, which has always been regarded as an innovative nation, mainly due to Silicon Valley's results. That nation begins to worry not only in generating technological innovations and mainly how to market the innovations that have been developed to reach favorable economic results. This concern is due to the speed at which Asians have beenplaying such innovations and then the marketing for the rest of the world, something easily possible after globalization (ERNST, 2005).

In Europe, higher education is now also one of the main instruments. The main adversity faced by countries concerns to high unemployment, which can be minimized with the generation of labor, skilled labor, influencing productivity, and the training of entrepreneurs. Undertakingresults in job creation, something that is critical to the economic performance of European countries in the coming decades (EUROPEAN COMISSION, 2011).

On the other hand, continents like South America and Asia, especially the countries Brazil, China and India, have been living a moment of progress to be considered the main emerging economies. The crisis affecting the developed countries eventually make room for the growth of emerging countries that understood the importance of higher education and gradually has improved their indicators. Investments in education have a direct impact on innovation, it can be seen in oil exploration, ore, in producing software or even electronic equipment, measures which are responsible for the good results of the countries (ARMIJO (2007).

The information cited above show the significance of the effects of globalization worldwide, with a profound impact on education (especially in higher education) and financing that composes it.

From globalization, there is a worldwide need for higher levels of education, resulting in a large increase in demand 
and access of students seeking the third degree. Ilon (2010) shows that between 1975 and 1995 there was a considerable increase in students enrolled in higher education in the world, out of 40.3 million, going to 80.5 million, almost doubled in just 20 years.

Delimiting the developed countries, Lazerson (2010) argues that globalization was responsible for promoting competition for financial resources between countries and universities, promoting changes in their funding. These features are achieved through the scientific and technological innovation through the generation of patents, given that represent concrete results to the market. Additionally, students begin to seek higher education courses according to the shortage of labor, skilled labor, making both economy and market beacon offers of higher education.

\section{Metodology}

The seek for progress, democratization, access to the common good and reducing inequality is a problem that has been fought for decades in Brazil, challenging public policies and economic theories developed for this purpose. Pigatto et al. (2010, p. 821), asks: "[...] why after so many years of investment it still cannot achieve a reasonable degree of development?"

In order to strengthen relations between public administration and the performance of higher education, this section explores planning, finance and public budget followed by the world higher education challenges.

\subsection{Planning, Finance And Public Budget}

According to Polo (2009), planning and budgeting are mixed in public administration. The author explains that, with respect to the public sector, the budget has been in practice, one of the only steps used in a planning system, but being perceived as a legal instrument, in which the executive branch gets legislative authorization to perform public spending. This lack of an effective planning process of the public sector makes the focus on the financial dimension grows, by means of public finances and the public budget process.

Under these circumstances, budgeting, whosegoals should only become viable and compatible set out in the decision-making process (Multi-Year Plan) with the available resources, shall exercise simultaneously the two roles: budgeting and planning (POLO, 2009, p 18.).

Note that since its inception, public finances concluded that the most objective is to enable the Federal Government's responsibilities. This analysis is guided in understanding the collection and use of resources for a predetermined order. The setting is usually associated with people's needs, to meet the public interest of the majority, therefore, the Federal Government should take care to not only get the resources, but also manage them and apply them through the known requirements. For D'Auria $(1962$, p. 63) public finances "[...] in its vast and limitless activities, face and resolve the problems of an economic nature that trigger the government function, from which it follows that the function financial falls under the political and economic order of the Federal Government".

Silva (2004) believes that, so that public resources are allocated efficiently, incentive mechanisms should be defined, aimed at prioritizing the effectiveness of public spending and especially the improvement of social indicators, as investments in health and education represent a positive impact with regard to the country in productivity and hence workers' income. In a study of consolidation of various indicators, it was shown to the extent the number of members of a Brazilian family with the third degree increases, as the investment by the family in higher education is also increased, demonstrating that as a first step the government, the population itself can feed back the investment in higher education (COSTA; COSTA, MELO, 2011).

However, for that intent, it is intended the required amount to the above sectors, the government needs resources that will be the basis to develop public policies and social actions that should designate their resources for the entire population. It is through obtaining public revenues that this whole process is designed (FUNG, 2004). Therefore, the proper management and use of financial resources represent improvements in social, administrative and economic aspects of public management, which will grant to fund the public funds activities from companies and people who will go to the government, performing a financial cycle from a society-state partnership (MATIASPEREIRA, 2006).

The society-state relationship then proceeds to guide the precepts of the area of public finances. Summarily, public finances should be concerned first with the activity of raising the funds through the tax of the government policies, and subsequently with the application of funds raised through a budgetary policy in order to meet the needs of the population (MATIAS-PEREIRA, 2006).

In this scenario, the government has a crucial role as it will be responsible for managing and allocating the necessary resources in public services that meet the interests and aspirations of society, either at the federal, state 
or local level (MATIAS-PEREIRA, 2006).

To meet these aspirations, which are growing, public entities need to manage public resources, turned directly to the implementation of activities that are of public interest, both as a state organization and as a community population (BOBBIO, 1986). It is then up to the government to conduct the public initiatives, as a tool Branches and agencies that compose it to meet the company's needs with services, activities and quality of public policies (MEIRELLES, 2012). To Matias-Pereira (2006), the search for an efficient public management then starts to represent a major challenge to the Federal Government, at all levels, it will involve an understanding of the demands of society and, from that, to trace the appropriate action, which involves planning, direction, control, among many other activities. In order to achieve effectiveness in these actions, a proper management of financial resources is needed, something that can be achieved by a well-designed budget.

The budget may be visible as a managerial tool that allows managers to evaluate the financial performance of an organization, its positive and negative impacts, the changes that occur in a given period of time, in order to understand in a macro and a micro environments, the application of financial resources, thus, the budget, both in public and in private initiative, concerns the composition of the interests of their organizations, showing different needs for each environment (GIACOMONI, 2012).

Since there is no change strategies in organizations, in any administrative dependence, there is also a budget amendment, which ultimately reflects these changes.

The budget has been practiced for many years, as noted by Deodado (1965), Lee and Johnson (1977) and Giacomoni (2012). The authors report that from feudalism to modern society, this instrument is a key to achieving greater transparency, control, planning and decision aid when applying the financial resources in organizations.

As regards the public area, budgetary practice has become a tool even for monitoring the population against their rulers, considering that they should try to allocate the necessary resources to address the demands of society. Based on the observed results (for example, education, safety, health, among other areas) the officials may have a hard recovery of the population (PAYSANT, 1999).

From then, it is evident the important role played by the Federal Government in the context of public finances and the public budget. Crozier (1996) believes that the Federal Government should seek more effective action and have to set targets to avoid the generation of vague and inconsistent results.

\subsection{World Higher Education Challenges}

At the end of the first decade and the beginning of the second decade of this century, many nations, especially those developed, have faced one of their greatest financial crises. Continents hitherto economically sound, like North America and Europe are the main affected, especially the United States, which shall have its hegemony threatened by China (SAWAYA, 2009). That situation makes these continents start to rethink a number of cyclical changes and even structural seeking resume good growth rates.

Amid the unwanted situations, some instruments are now considered essential to improve economic indicators, including higher education, which is responsible for several factors that have a direct impact on the results of the economy, such as:

a) generation of labor, skilled labor, which causes direct impact on productivity and consequently in job creation;

b) innovation discoveries, which when well-marketed can also help in the economic progress of countries and generating jobs;

c) creation of new business and maintain existing business, by training entrepreneurs.

Factors such as these make the nations start to give even more attention to higher education and funding should be allocated for such, as the United States, which has always been regarded as an innovative nation, mainly due to Silicon Valley's results. That nation begins to worry not only in generating technological innovations and mainly how to market the innovations that have been developed to reach favorable economic results. This concern is due to the speed at which Asians have beenplaying such innovations and then the marketing for the rest of the world, something easily possible after globalization (ERNST, 2005).

In Europe, higher education is now also one of the main instruments. The main adversity faced by countries concerns to high unemployment, which can be minimized with the generation of labor, skilled labor, influencing productivity, and the training of entrepreneurs. Undertakingresults in job creation, something that is critical to the economic performance of European countries in the coming decades (EUROPEAN COMISSION, 2011). 
On the other hand, continents like South America and Asia, especially the countries Brazil, China and India, have been living a moment of progress to be considered the main emerging economies. The crisis affecting the developed countries eventually make room for the growth of emerging countries that understood the importance of higher education and gradually has improved their indicators. Investments in education have a direct impact on innovation, it can be seen in oil exploration, ore, in producing software or even electronic equipment, measures which are responsible for the good results of the countries (ARMIJO (2007).

The information cited above show the significance of the effects of globalization worldwide, with a profound impact on education (especially in higher education) and financing that composes it.

From globalization, there is a worldwide need for higher levels of education, resulting in a large increase in demand and access of students seeking the third degree. Ilon (2010) shows that between 1975 and 1995 there was a considerable increase in students enrolled in higher education in the world, out of 40.3 million, going to 80.5 million, almost doubled in just 20 years.

Delimiting the developed countries, Lazerson (2010) argues that globalization was responsible for promoting competition for financial resources between countries and universities, promoting changes in their funding. These features are achieved through the scientific and technological innovation through the generation of patents, given that represent concrete results to the market. Additionally, students begin to seek higher education courses according to the shortage of labor, skilled labor, making both economy and market beacon offers of higher education.

$$
\begin{aligned}
E(\text { Indicator })= & \exp \left\{\beta_{0}+\beta_{1}(\text { Time })+\beta_{2} I(\text { Country }=\text { China })+\beta_{3} I(\text { Country }=\text { Canada })\right. \\
& \left.+\beta_{4} I(\text { Country }=\text { China })(\text { Time })+\beta_{5} I(\text { Country }=\text { Canada })(\text { Time })\right\}
\end{aligned}
$$

In the model above, the reference country was Brazil and the time ranged in most indicators from 2003 to 2012. Considering Brazil as reference, $\exp \left(\beta_{1}\right)$ indicate in percentage how much on average the indicator grows annually, $\exp \left(\beta_{1}+\beta_{4}\right)$ and $\exp \left(\beta_{1}+\beta_{5}\right)$ indicates in percentage how much on average the indicator grows annually in China and Canada respectively.

The results found by this method were then presented in comparative evolution of tables, representing the performance of each country

\section{Cross-Compare Analysis: Educational Indicators In Brazil, Canada And China}

In order to understand the performance of the educational indicators that impact the countries, a comparative analysis by regression models via log-linear Quasi-Likelihood method of the following indicators was carried out:

a) General investment in higher education (\% of GDP);

b) General investment in higher education (\% GDP) versus GDP per capita in US dollars;

c) number of gross enrollment of the population;

d) number of net enrollment (18 to 24 years) of the population;

e) spending on research and development of the GDP;

f) researchers in R\&D per million people;

g) professor salary (as no significant changes in the period, the professor salary indicator was collected only for the year 2012).

The goal was to understand the performance of each of these indicators in their countries in order to understand their behavior in the 2003-2012 period.

\subsection{General Investment In Higher Education (\% Of GDP)}

A key indicator to analyze the importance that a nation gives to higher education is the percentage of GDP invested. In Table 1, the overall investment can be evaluated in higher education (percentage of GDP) over time by country.

Table 1: Comparative evolution of the general investment in higher education (\% of GDP) from 2003 to 2012.

\begin{tabular}{llll}
\hline \multicolumn{4}{l}{ General Investment in Higher Education (\% GDP) } \\
\hline Year & Brazil & Canada* & China \\
\hline 2003 & $0.9 \%$ & $2.4 \%$ & $1.1 \%$ \\
2004 & $0.8 \%$ & $2.4 \%$ & $1.0 \%$ \\
2005 & $0.9 \%$ & $2.4 \%$ & $1.0 \%$ \\
2006 & $0.8 \%$ & $2.7 \%$ & $1.0 \%$ \\
2007 & $0.8 \%$ & $2.6 \%$ & $1.2 \%$ \\
2008 & $0.9 \%$ & $2.5 \%$ & $1.2 \%$ \\
2009 & $0.9 \%$ & $2.5 \%$ & $1.2 \%$
\end{tabular}




\begin{tabular}{llll}
2010 & $0.9 \%$ & $2.6 \%$ & $1.3 \%$ \\
2011 & $1.0 \%$ & $2.8 \%$ & $1.4 \%$ \\
2012 & $1.0 \%$ & - & $1.5 \%$ \\
\hline \multicolumn{2}{l}{ Log-Linear Model } & & \\
\hline $\exp \left(\beta_{1}\right)$ & 1.019 & 1.015 & 1.044 \\
C.I. - 95\% & {$[1.003 ; 1.034]$} & {$[1.004 ; 1.025]$} & {$[1.031 ; 1.058]$} \\
\hline \hline
\end{tabular}

Source: Prepared by the author with data from Brazil, INEP (2014); Canada, World Bank (2014) and OECD (2013); and China for years 2003 and 2004, USCI (2014), for the year 2005, CHINA.ORG (2014), for years 2006 to 2012, China Daily (2014).

* Note: The percentage invested in 2012 by Canada was not released until the end of the data collection stage.

It is interesting to note that:

a) the general investment in higher education (percentage of GDP) in Brazil rose from $0.9 \%$ in 2003 to $1.0 \%$ in 2012 , and the average annual increase for the period was $1.9 \%(0.3 \%, 3.4 \%)$;

b) the general investment in higher education (percentage of GDP) in Canada increased from $2.4 \%$ in 2003 to $2.8 \%$ in 2012 , with the average annual increase in the period by $1.5 \%(0.4 \%, 2.5 \%)$. It can be observe a slight decrease between the years 2007 to 2009 due to an international crisis of the time. From 2010 Canada resumes growth in investment;

c) the general investment in higher education (percentage of GDP) in China rose from $1.1 \%$ in 2003 to $1.5 \%$ in 2012, and the average annual increase for the period was $4.4 \%(3.1 \%, 5.8 \%)$;

d) Brazil showed a statically equal growth of Canada during the study period, but the average value of the general investment in higher education (\% of GDP) in Canada was 2.5\%, while in Brazil was $0.89 \%$.

\subsection{General Investment In Higher Education (\% Gdp) Versus Gdp Per Capita}

Since the gross GDP of each country is essentially different and it cannot judge the economic situation and the investment of a country only by its gross GDP, working with the GDP per capita for this reason presents a more realistic perspective of that nation's economic situation. From the moment that one has the percentage of GDP applied in higher education and GDP per capita in the country, this section is a correlation between the two indicators in order to understand what the gross amount, in dollars, would be applied in higher education for each individual, including also those who are not part of the system, in order to understand the possibilities that the nations grant their inhabitants.

In Table 2, it can be assessed the general investment in higher education (\% GDP) versus GDP per capita over time by country.

Table 2: Comparative evolution of the general investment in higher education (\% of GDP) versus GDP per capita from 2003 to 2012.

\begin{tabular}{llll}
\hline \multicolumn{4}{l}{ General investment in higher education (\%GDP) versus } \\
\hline Year & Brazil & Canada & Per Capita (\$ dollar) \\
\hline 2003 & 27.33 & 674.59 & 13.94 \\
2004 & 28.86 & 765.55 & 14.84 \\
2005 & 42.64 & 866.16 & 17.35 \\
2006 & 46.30 & $1,085.43$ & 21.06 \\
2007 & 57.56 & $1,149.23$ & 31.51 \\
2008 & 77.63 & $1,155.98$ & 40.63 \\
2009 & 75.35 & $1,015.48$ & 45.34 \\
2010 & 98.80 & $1,229.67$ & 56.89 \\
2011 & 125.78 & $1,444.38$ & 74.83 \\
2012 & 113.46 & - & 91.04 \\
\hline Log-Linear Model & \multicolumn{3}{l}{} \\
\hline exp $\left(\beta_{1}\right)$ & 1.183 & 1.081 & 1.251 \\
C.I. - 95\% & {$[1.121 ; 1.250]$} & {$[1.064 ; 1.098]$} & {$[1.161 ; 1.349]$} \\
\hline \hline
\end{tabular}

Source: Prepared by the author with data from UNSD (2014) and Table 1.

It is interesting to note that:

a) the general investment in higher education (\% of GDP) versus GDP per capita in Brazil increased from 27.33 in 2003 to 113.46 in 2012, and the average annual increase in the period was $18.3 \%$ (12.1\%;25.0\%); 
b) the general investment in higher education (\% of GDP) versus GDP per capita in Canada increased from 674.59 in 2003 to $1,444.38$ in 2011 , with the average annual increase for the period by $8.1 \%(6.4 \% ; 9.8 \%)$. It is worth mentioning a sharp decline in 2009 , caused by the international crisis of the time;

c) the general investment in higher education (\% of GDP) versus GDP per capita in China rose from 13.94 in 2003 to 91.04 in 2012, with the average annual increase for the period by $25.1 \%(16.1 \% ; 34.9 \%)$;

d) both Brazil and China showed a statistically higher growth than Canada, which is extremely relevant. On the other hand, the overall investment in medium higher education period in Canada (\% of GDP) versus GDP per capita was about 15 times of Brazil and 25 times of China, which can be explained by the fact that Canada is the nation that invests more in education and has a significantly lower population among the three countries.

\subsection{Gross Enrollment Rate}

The gross enrollment rate includes the total percentage of enrollments in higher education considering all ages. This is a representative value in nations such as Brazil and China due to the supply deficit that has accumulated over the years. In Table 3, it can be evaluated the percentage of the registered population over time by country.

Table 3: Comp. evolution of the gross enrollment rate from 2003 to 2012.

\begin{tabular}{lccc}
\hline \multicolumn{4}{l}{ Number of gross enrollment $-\%$ of the population } \\
\hline Year & Brazil & Canada & China \\
\hline 2003 & $18.6 \%$ & $57.5 \%$ & $15.0 \%$ \\
2004 & $18.6 \%$ & $60.5 \%$ & $17.0 \%$ \\
2005 & $19.9 \%$ & $61.3 \%$ & $18.3 \%$ \\
2006 & $22.6 \%$ & $62.0 \%$ & $19.5 \%$ \\
2007 & $24.3 \%$ & $62.4 \%$ & $20.0 \%$ \\
2008 & $25.5 \%$ & $63.1 \%$ & $20.2 \%$ \\
2009 & $26.7 \%$ & $63.5 \%$ & $21.8 \%$ \\
2010 & $27.8 \%$ & $68.4 \%$ & $23.3 \%$ \\
2011 & $27.8 \%$ & $69.5 \%$ & $24.3 \%$ \\
2012 & $28.7 \%$ & $69.7 \%$ & $26.7 \%$ \\
\hline Log-Linear Model & & \\
\hline exp $\left(\beta_{1}\right)$ & 1.054 & 1.021 & 1.057 \\
C.I. $-95 \%$ & {$[1.046 ; 1.062]$} & {$[1.016 ; 1.025]$} & {$[1.049 ; 1.066]$} \\
\hline \hline
\end{tabular}

Source: Prepared by the author with data from Brazil, Paim (2014); Canada, Statistics Canada (2014); and China, UNESCO (2014).

It is interesting to note that:

a) the percentage of the population enrolled in Brazil went from $18.6 \%$ in 2003 to $28.7 \%$ in 2012, and the average annual increase for the period was $5.4 \%(4.6 \% ; 6.2 \%)$;

b) the percentage of the registered population in Canada increased from $57.5 \%$ in 2003 to $69.7 \%$ in 2012 , and the average annual increase for the period was $2.1 \%(1.6 \% ; 2.5 \%)$;

c) the percentage of the registered population in China increased from $15.0 \%$ in 2003 to $26.7 \%$ in 2012, and the average annual increase for the period was $5.7 \%(4.9 \% ; 6.6 \%)$;

d) although Brazil and China have shown an increase statistically above Canada, the percentage of registered population in Canada was higher than both countries. The growth of the gross rate in Brazil and China is due to the access that was promoted to groups previously excluded from the system.

4.4 Net Enrollment Rate

The net enrollment rate comprises the percentage of the enrolled students in higher education aged between 18 to 24 years, group considered "correct" to the third grade. Some countries, such as Brazil and China, face certain difficulties to increase the indicator of net enrollment by the fact they still rely on individuals of older ages who did not have access to higher education opportunity, and now return to studies seeking access. This rate is also used to measure the size of a system and can be classified as "elite system," "mass system" or "universal system" depending on the percentage achieved (TROW, 2006).

In Table 4, it can be evaluated the net enrollment rate (18 to 24) of the population over time by country.

Table 4: Comparative evolution of the net enrollment rate from 2003 to 2012.

\begin{tabular}{llll}
\hline \multicolumn{4}{l}{ Net enrollment rate (18 to 24 years) $-\%$ of the population } \\
\hline Year & Brazil & Canada & China \\
\hline 2003 & $12.2 \%$ & $32.3 \%$ & $9.0 \%$
\end{tabular}




\begin{tabular}{llll}
2004 & $12.4 \%$ & $34.1 \%$ & $10.2 \%$ \\
2005 & $13.2 \%$ & $34.5 \%$ & $11.0 \%$ \\
2006 & $14.6 \%$ & $34.1 \%$ & $11.7 \%$ \\
2007 & $15.5 \%$ & $35.1 \%$ & $12.0 \%$ \\
2008 & $16.2 \%$ & $35.4 \%$ & $12.1 \%$ \\
2009 & $17.5 \%$ & $35.8 \%$ & $13.1 \%$ \\
2010 & $18.3 \%$ & $38.2 \%$ & $14.0 \%$ \\
2011 & $18.3 \%$ & $39.0 \%$ & $14.6 \%$ \\
2012 & $18.8 \%$ & $39.1 \%$ & $16.0 \%$ \\
\hline Log-Linear Model & & \\
\hline exp $\left(\beta_{1}\right)$ & 1.054 & 1.020 & 1.057 \\
C.I. - 95\% & {$[1.047 ; 1.061]$} & {$[1.016 ; 1.025]$} & {$[1.049 ; 1.065]$} \\
\hline \hline
\end{tabular}

Source: Prepared by the author with data from Brazil, Paim (2014); Canada, Statistics Canada (2014); and China, UNESCO (2014).

It is interesting to note that:

a) the percentage of net population (18-24 years) enrolled in Brazil rose from $12.2 \%$ in 2003 to $18.8 \%$ in 2012 , and the average annual increase for the period was $5.4 \%(4.7 \% ; 6.1 \%)$;

b) the percentage of net population (18-24 years) registered in Canada increased from 32.3\% in 2003 to $39.1 \%$ in 2012 , and the average annual increase for the period was $2.0 \%(1.6 \% ; 2.5 \%)$;

c) the percentage of net population (18-24 years) registered in China rose from $9.0 \%$ in 2003 to $16.0 \%$ in 2012 , and the average annual increase for the period was $5.7 \%(4.9 \% ; 6.5 \%)$;

d) although Brazil and China have submitted a statistically superior growth than Canada, the percentage of net registered population (18-24 years) in Canada is considerably higher than in the two countries. This factor suggests that Canada is achieving some stabilization and Brazil and China also have significant space to expand access and percentage of the population between 18 and 24 covered by the third grade.

\subsection{Expenditure On Research And Development}

Expenditure on research and development has deep relationship with the investment in higher education in a country, which should be supported by the three pillars: education, research and extension. In the countries studied, a representative research is conducted within the universities, and funding largely comes from the government, or public funding. Seeking to understand the attention that each country gives this dimension, there was a comparative analysis of the percentage of GDP that is invested in research and development.

In Table 5, it can be evaluated the expenditure in research and development expenses as a percentage of GDP over time by country.

Table 5: Comp. evolution of expenditure on research and development from 2003 to 2012.

\begin{tabular}{llll}
\hline \multicolumn{5}{l}{ Expenditure on research and development (\% of GDP) } \\
\hline \multicolumn{1}{l}{ Year } & Brazil* & Canada & China \\
\hline 2003 & $0.96 \%$ & $2.04 \%$ & $1.13 \%$ \\
2004 & $0.90 \%$ & $2.07 \%$ & $1.23 \%$ \\
2005 & $0.97 \%$ & $2.04 \%$ & $1.32 \%$ \\
2006 & $1.01 \%$ & $2.00 \%$ & $1.39 \%$ \\
2007 & $1.10 \%$ & $1.96 \%$ & $1.40 \%$ \\
2008 & $1.11 \%$ & $1.92 \%$ & $1.47 \%$ \\
2009 & $1.17 \%$ & $1.97 \%$ & $1.70 \%$ \\
2010 & $1.16 \%$ & $1.86 \%$ & $1.76 \%$ \\
2011 & $1.21 \%$ & $1.79 \%$ & $1.84 \%$ \\
2012 & - & $1.73 \%$ & $1.98 \%$ \\
\hline Log-Linear Model & & \\
\hline exp $\left(\beta_{1}\right)$ & 1.036 & 0.982 & 1.062 \\
C.I. - $95 \%$ & {$[1.028 ; 1.045]$} & {$[0.977 ; 0.987]$} & {$[1.056 ; 1.069]$} \\
\hline \hline
\end{tabular}

Source: Prepared by the author with data from World Bank (2014)

* Note: The percentage spent by Brazil in 2012 had not been released by the end of the data collection stage.

It is interesting to note that: 
a) the percentage of GDP allocated to research and development in Brazil went from $0.96 \%$ in 2003 to $1.21 \%$ in 2011 , and the average annual increase for the period was $3.6 \%(2.8 \% ; 4.5 \%)$;

b) the percentage of GDP allocated to research and development in Canada increased from $2.04 \%$ in 2003 to $1.73 \%$ in 2012 , and the average annual decrease in the period was $1.8 \%(1.3 \% ; 2.3 \%)$;

c) the percentage of GDP for research and development in China increased from $1.13 \%$ in 2003 to $1.98 \%$ in 2012 , and the average annual increase for the period was $6.2 \%(5.6 \% ; 6.9 \%)$;

d) while Brazil and China increased by an average of GDP's percentage, Canada had been over the time decreasing its percentage of GDP allocated to research and development, especially after the 2008 crisis, a major factor in the observed results. It is worth noting that in 2011 China surpasses Canada in the percentage of investments in research and development.

\subsection{Researchers In R\&D}

In order to complement the indicator "Expenditure on research and development" presented in the previous section, the index "Researchers in R\&D" (per million people) has the intention to understand the intellectual formation incentive and especially the search for innovation and development of countries studied. The combination of the two indicators provides a map of the concern of nations investing in $\mathrm{R} \& \mathrm{D}$ as a key factor for progress.

In Table 6, the number of researchers can be evaluated in research and development (million people) over time by country.

Table 6: Comp. evolution of total researchers from 2003 to 2012.

\begin{tabular}{llll}
\hline \multicolumn{4}{l}{ Researchers in R\&D (per million people) } \\
\hline Year & Brazil & Canada & China \\
\hline 2003 & 495.28 & $3,900.72$ & 661.73 \\
2004 & 544.74 & $4,085.34$ & 706.84 \\
2005 & 587.78 & $4,238.35$ & 848.67 \\
2006 & 597.01 & $4,313.27$ & 922.79 \\
2007 & 611.96 & $4,587.73$ & $1,066.73$ \\
2008 & 628.52 & $4,710.83$ & $1,185.95$ \\
2009 & 667.23 & $4,450.62$ & 852.78 \\
2010 & 710.28 & $4,578.88$ & 890.44 \\
2011 & - & $4,562.82$ & 963.20 \\
2012 & - & - & $1,019.57$ \\
\hline Log-Linear Model & & 1.035 \\
\hline exp $\left(\beta_{1}\right)$ & 1.045 & 1.019 & {$[1.012 ; 1.059]$} \\
C.I. - 95\% & {$[1.005 ; 1.087]$} & {$[1.007 ; 1.031]$} & \\
\hline \hline
\end{tabular}

Source: Prepared by the author with data from World Bank (2014)

* Note: The percentage spent by Brazil in the years 2011 and 2012, and Canada in 2012 had not been released by the end of the data collection stage.

It is interesting to note that:

a) the number of researchers in R\&D (per million people) in Brazil went from 495.28 in 2003 to 710.28 in 2010 , and the average annual increase for the period was $4.5 \%(0.5 \% ; 8.7 \%)$;

b) the number of researchers in R\&D (per million people) in Canada increased from 3,900.72 in 2003 to $4,562.82$ in 2011 , with the average annual increase for the period by $1.9 \%(0.7 \% ; 3,1 \%)$;

c) the number of researchers in R\&D (per million people) in China increased from 661.73 in 2003 to $1,019.57$ in 2012 , with the average annual increase for the period by $3.5 \%(1.2 \% ; 5,9 \%)$;

d) although Brazil and China have submitted a statistically higher growth than Canada, the average number of researchers of the period in Canada was about 6 times higher than Brazil and 5 times than China. It is worth highlighting that the year 2009 was decreased to Canada and China, which then they start a small descent. This phenomenon can be explained by the 2008 crisis, where countries have had to reduce some costs. This non-linear growth meant that China's annual average surpassed Brazil, although Brazil has a more significant difference considering only the years 2003 and 2010.

\subsection{Professor Salary}

The salary of full-time professors in higher education is an important indicator as it shows the appreciation that the country grants to the principal human resource in the educational process of the students. In Table 7, it can be evaluated professors average salary ( $\$$ dollar) executed in the three countries, for full-time professors. Since there 
were no significant changes during the study period, it presents the average professor salary referring only to the year 2012:

Table 7: Average full-time professor salary: Year 2012.

\begin{tabular}{llll}
\hline \multicolumn{4}{l}{ Professor average salary (monthly) } \\
\hline Year & Brazil & Canada time (U.S PPP dollar) & \\
\hline 2012 & $3,179.00$ & $7,196.00$ & China \\
\hline
\end{tabular}

Source: Prepared by the author with data from Altbach et al. (2012).

When analyzing the professors average salary (monthly), a large discrepancy is observed amongthe three countries, especially China, which has 4 times less pay than the salary of Brazil and almost 10 times less than the salary of Canada. However, to mitigate this type of diversion, it must be combined the professor average salary with the index Consumer Price Index, which reflects changes in the cost for the average consumer in the purchase of a basket of goods and services which may be fixed or changed at specific intervals, yearly normally. The Laspeyres formula is generally used for the calculation of this index (WORLD BANK, 2014). The Table 8 presents the consumer price index for the year 2012:

Table 8: Consumer price index.

\begin{tabular}{llll}
\hline \multicolumn{2}{l}{ Consumer Price Index $(\$$ dollar $)$} & & \\
\hline Year & Brazil & Canada & China \\
\hline 2012 & 46.08 & 92.98 & 17.31 \\
\hline
\end{tabular}

Source: Prepared by the author with data from World Bank (2014).

By analyzing Table 7 along with Table 8 , we get Table 9, which shows how many "baskets of goods" an individual can purchase with monthly professor salary in his/her country:

Table 9: Basket of goods on professor salary.

\begin{tabular}{lccc}
\hline \multicolumn{4}{l}{ Professor salary vs. Consumer Price Index } \\
\hline Year & Brazil & Canada & China \\
\hline 2012 & 68.98 & 77.39 & 41.59 \\
\hline
\end{tabular}

Source: Prepared by the author with data in Tables 7 and 8 .

From the Table 9 data, it can be concluded that Canadian professors have the best pay, but it is not as representative for the Brazil in relation to the acquisition of goods and services. The salary practiced in China in terms of acquiring a basket of goods and services is 1.65 lower than in Brazil and 1.8 lower than in Canada, demonstrating a significant correction to the differences observed in pure analysis of Table 7.

\section{Conclusões}

After analyzing the data, it can be draw conclusions in each variable when analyzing comparatively the three countries.

The General Investment in Higher Education (\% of GDP) highlighted the reasons that make China has the world's largest educational system. Although smaller than Canada in percentage terms, the average annual increase in the percentage of GDP applied in higher education was 4.4\%, which is twice the size of Brazil and 3 times higher than Canada. Keeping this ratio, China tends to have the best funded higher education system in the world in the upcoming decades.

Regarding the general investment in higher education (\% GDP) versus GDP per capita, China also stood out, driven by the expansion of resources applied in the third degree, as already explained. The annual growth rate in this indicator was $25.1 \%$, a significant amount and confirms the expansion observed in the system.

The gross enrollment rate and net enrollment rate also had a higher average annual growth in China and Brazil, respectively. Such behavior can be justified due to the fact that Canada has reached a satisfactory level of higher education system expansion, different from China and Brazil that still have a buildup of individuals who have not yet glimpsed the higher education on the horizon of their lives. It can be concluded with the results of these indicators that both China and Brazil need to invest even more in this level of education and design effective actions and policies in order to reduce this gap present in the system.

Expenditure on research and development (\% of GDP) also emphasized the importance that China has granted to 
the segment. The country has an average annual growth of $6.2 \%$, up from 1.5 times the average growth observed in Brazil and more than 3 times the average growth observed in Canada. The three countries also showed average growth in the number of researchers per million people which reinforces some concern about the inseparability of teaching and research in higher education institutions.

Chart 1: Summary of observed effects on the quantitative analysis of indicators.

\begin{tabular}{|l|l|}
\hline \multicolumn{1}{|c|}{ Indicator (s) } & \multicolumn{1}{c|}{ Main effects } \\
\hline $\begin{array}{l}\text { General Investment in } \\
\text { Higher Education }\end{array}$ & $\begin{array}{l}\text { Especially China, whose share of GDP applied in higher education was 4.4\%, } \\
\text { which is twice the size of Brazil and 3 times higher than Canada. }\end{array}$ \\
\hline $\begin{array}{l}\text { Investment in higher } \\
\text { education (\% GDP) } \\
\text { versus GDP per capita }\end{array}$ & $\begin{array}{l}\text { China also stood out, driven by the expansion of resources applied in the third } \\
\text { degree. The annual growth rate was 25.1\%. }\end{array}$ \\
\hline Gross/Net Enrollment & $\begin{array}{l}\text { Both China and Brazil need to invest even more in this level of education and } \\
\text { design effective actions and policies in order to reduce this gap present in the } \\
\text { system. }\end{array}$ \\
\hline $\begin{array}{l}\text { Expenditure on research } \\
\text { and development }\end{array}$ & $\begin{array}{l}\text { China stood out with average annual growth of 6.2\%, up from 1.5 times of Brazil } \\
\text { and more than 3 times of Canada. }\end{array}$ \\
\hline $\begin{array}{l}\text { Researchers per million } \\
\text { people }\end{array}$ & $\begin{array}{l}\text { It has increased, which reinforces some concern about the inseparability of } \\
\text { teaching and research in higher education institutions. }\end{array}$ \\
\hline Professor Salary & $\begin{array}{l}\text { Canadian professors have the best pay, but it is not as representative for the Brazil } \\
\text { in relation to the acquisition of goods and services. The salary practiced in China } \\
\text { in terms of acquiring a basket of goods and services is 65\% lower than in Brazil } \\
\text { and 80\% lower than in Canada. }\end{array}$ \\
\hline
\end{tabular}

Source: Prepared by the author.

The conclusions regarding the comparative analysis of these indicators showed that Canada is a country that has already achieved a high level of development, including its higher education, and that can be considered a reference for other nations seeking to achieve similar progress as Brazil and China themselves. In addition, China, a member of the BRICS, which is a pair of Brazil, has been able to achieve satisfactory results in the indicators that guide higher education, which highlighted the advantages of conducting a benchmarking of their actions and policies, that until a few decades ago, Brazil surpassed China in all educational indicators. Both perceptions then reinforced the need to correlate the indicators for the three countries in order to identify their significance and those who should be better monitored.

\section{Referências}

ALTBACH, P. G.; REISBERG, L.; YUDKEVICH, M.; ANDROUSHCHAK, G.; e PACHECO, I. F. Paying the professoriate: a global comparison of compensation and contracts. New York, Abingdon: Routledge /Taylor and Francis, 2012.

ARMIJO, L. E. The BRICs Countries (Brazil, Russia, India, and China) as Analytical Category: Mirage or Insight? Asian Perspective, Portland, v. 31 n.4, p. 7-42, 2007.

BARBETTA, P. A. Estatística aplicada às ciências sociais. 7th. ed. Rev. Florianópolis, SC: Editora da UFSC, 2008.

BARROS, A. J. S.; LEHFELD, N. A. S. Fundamentos de Metodologia Científica. 3. ed. São Paulo: Prentice-Hall, 2007.

BOBBIO, N. O futuro da democracia. Rio de Janeiro: Paz e Terra, 1986.

BID. Empreendedorismo em Economias Emergentes: Criação e Desenvolvimento de Novas Empresas na América Latina e no Leste Asiático. Inter-American Development Bank. Nova York. Março de 2002.

CAPES. Seminário sobre internacionalização da Educação Superior entre Brasil e China acontece em Pequim. Brasília. 2012. Disponível em: < http://www.capes.gov.br/servicos/sala-de-imprensa/36-noticias/5330-seminariosobre-internacionalizacao-da-educacao-superior-entre-brasil-e-china-acontece-em-pequim>. Acesso em 26 de Fevereiro de 2017.

CATTANI, D. A. Desigualdades socioeconômicas Brasil/Canadá: um estudo a partir dos extremos. Revista Interfaces Brasil/Canadá, Porto Alegre, n.6, 2006.

CHINA.ORG. China Spends 2.82\% of GDP in Education. Portal China.org.cn. Pequim, China. Disponível em: $<$ http://www.china.org.cn/english/MATERIAL/194843.htm>. Acesso em 18 de Setembro de 2014.

CHINA DAILY. Govt spends chunk of GDP on education. Portal China Daily. Pequim, China. Disponível 
em:<http://www.chinadaily.com.cn/bizchina/2011-07/16/content_12916109.htm>. Acesso em 18 de Setembro de 2014.

COSTA, D. M. ; COSTA, A. M. ; MELO, P. A. . A Retroalimentação da Educação Superior no Brasil. Pretexto, Belo Horizonte, v. 12, p. 61-84, 2011.

CROZIER, Michael. La transación del paradigma burocrático e una cultura de gestión pública. In: CONGRESSO INTERAMERICANO DEL CLAD SOBRE A REFORMA DEL ESTADO Y DE LA ADMINISTRACIÓN PÚBLICA, 1996, Rio de Janeiro. Anais... Rio de Janeiro, 1996.

D’ÁURIA, F. Ciência das finanças: teoria e prática. 2nd. ed. São Paulo: Companhia Editora Nacional. 1962.

DEODATO, A. Manual de ciência das finanças. 9th ed. São Paulo: Saraiva, 1965.

ERNST, D. Pathways to innovation in Asia's leading electronics-exporting countries: a framework for exploring drivers and policy implications. Int. J. Technology Management, Olney, v. 29, n. 1/2, p. 6-20. 2005.

EUROPEAN COMMISSION. Anual Growth Survey: Progress report on Europe 2020. Brussels, COM (2011) 11 - a1/2. 2011.

FUNG, A. Receitas para esferas públicas: oito desenhos institucionais e suas conseqüências; In: COELHO, V. S. P; NOBRE, M. (Orgs). Participação e Deliberação: teoria democrática e experiências institucionais no Brasil contemporâneo, São Paulo: Editora 34, 2004. cap. 8, p. 173-209.

GIACOMONI, J. Orçamento público. 16th. ed. São Paulo: Atlas, 2012.

HADDAD, Sérgio; GRACIANO, Mariângela. Educação: direito universal ou mercado em expansão. São Paulo Perspec., São Paulo, vol.18, n.3, pp. 67-77, 2004.

ILON, L. Higher Education Responds to Global Economic Dynamics. In: RUST, V.; PORTNOI, L.; BAGLEY, S. (Orgs.). Higher Education, Policy and the Global Competition Phenomenon. New York: Palgrave Macmillan, 2010.

INEP. Percentual do Investimento Total em Relação ao PIB por Nivel de Ensino. Instituto Nacional de Estudos e Pesquisas Educacionais Anísio Teixeira. Brasília. Disponível em: $<$ http://portal.inep.gov.br/web/guest/estatisticasgastoseducacao-indicadores_financeiros-p.t.i._nivel_ensino.htm>. Acesso em 18 de Setembro de 2014.

ISTP Canada. Brazil Program Overview. Disponível em <http://www.istpcanada.ca/international_programs/Brazil/>. Acesso em 30 de Março de 2017.

LANG, D.; ZHA, Q. Comparing University: A Case Study between Canada and China. Higher Education Policy, Paris, v.17, n.4, p.339-381, 2004.

LAZERSON, M. Higher Education and the American Dream: Success and its Discontents. Budapest: Central European University Press, 2010.

LEE, R. D.; JOHNSON, R. W. Public budgeting systems. 2nd. ed. Baltimore: University Park Press, 1977.

MAHMOOD, P. I.; SINGH J. Technological Dynamism in Asia. Research Policy, Vol. 32, N. 6, p. 1031-1054. 2003.

MATIAS-PEREIRA, J. Finanças públicas: a política orçamentária no Brasil. 3rd. ed. São Paulo: Atlas. 2006.

McCUlLAGH, P.; NELDER, J. A. Generalized Linear Models. London: Chapman and Hall, 1989.

MEIRELLES, H. L. Direito administrativo brasileiro. 38th. ed. São Paulo: Malheiros Editores. 2012.

OECD. Education at a Glance 2013: OECD Indicators. Paris: OECD Publishing, 2013.

PAIM, H. Ensino Superior e novas tecnologias: caminhos e desafios. Brasília: Ministério da Educação, 2014.

PAYSANT, A. Finances publiques. 5th. ed. Paris: Armand Colin, 1999.

PIGATTO, J. A. M.; HOLANDA, V. B.; MOREIRA, C. R.; CARVALHO, Frederico A. A importância da contabilidade de competência para a informação de custos governamental. Rev. Adm. Pública, Rio de Janeiro, v. 44, n. 4, p. 821-37, 2010.

POLO, J. C. Planejamento e Orçamento no Município. São Paulo: Programa de Gestão Governamental, 2009.

SAWAYA, R. R. Crise: um problema conjuntural ou da lógica da acumulação mundial?. Estud. av., São Paulo, v. 23, n. 66, 2009.

SANCHES, O. M. Dicionário de orçamento, planejamento e áreas afins. Brasília: OMS, 2004.

SILVA, L. M. Contabilidade governamental: um enfoque administrativo. 7th. ed. São Paulo: Atlas, 2004.

STATISTICS CANADA. Education, training and learning. Ottawa. Disponível em: 
$<$ http://www5.statcan.gc.ca/subject-sujet/theme-theme.action?pid=1821\&lang=eng\&more $=0 \& H P A>$. Acesso em 18 de Setembro de 2014.

TROW, M. Reflection on the Transition from Elite to Mass to Universal Access: Form and Phases of Higher Education in Modern Societies since WWII. In: J. FOREST and P. ALTBACH (orgs.), International Handbook of Higher Education. Netherlands: Springer, 2006.

UNESCO. Education for All: Overcoming inequality: why governance matters. Global Monitoring Report 2009. Reino Unido: United Nations Educational, Scientific and Cultural Organization, 2008.

UNESCO. Data Centre: UNESCO Institute for Statistics. Montreal: United Nations Educational, Scientific and Cultural Organization. Disponível em: <http://data.uis.unesco.org/>. Acesso em 18 de Setembro de 2014.

UNSD. Per capita GDP at current prices - US dollars. Nova York: United Nations Statistics Division of the Department of Economic and Social Affairs (DESA). Disponível em: <http://data.un.org/ >. Acesso em $07 \mathrm{de}$ Novembro de 2014.

USCI. Education and Government Efforts. Los Angeles: University of Southern California U.S.-China Institute. 2014. <http://china.usc.edu/\%28S\%28qgpbj1yqm4431a315gsx5m55\%29X\%281\%29A\%28KC50L0V20AEkAAAAM 2NiOTRhMTQtOWNhZi00YWFjLTk4YzUtMmVjYzg1YTg4OTFjcGO62MXcRjByew2Edf8IOjdExCc1\%29\% 29/ShowAverageDay.aspx?articleID=615\&AspxAutoDetectCookieSupport=1>. Acesso em 18 de Setembro de 2014.

WEDDERBURN, R. W. M. Quasilikelihood functions, generalized linear models and the Gauss-Newton method. Biometrika, Oxford, p. 439-47, 1974.

WORLD BANK. World Development Indicators. Washington. Disponível em: $<\mathrm{http}: / /$ databank.worldbank.org $>$. Acesso em 07 de Novembro de 2014.

*Acknowledgments: I'm grateful for the contribution of Professor Paul Axelrod of York University (YorkU) for suggesting the databases for Canada research. 